
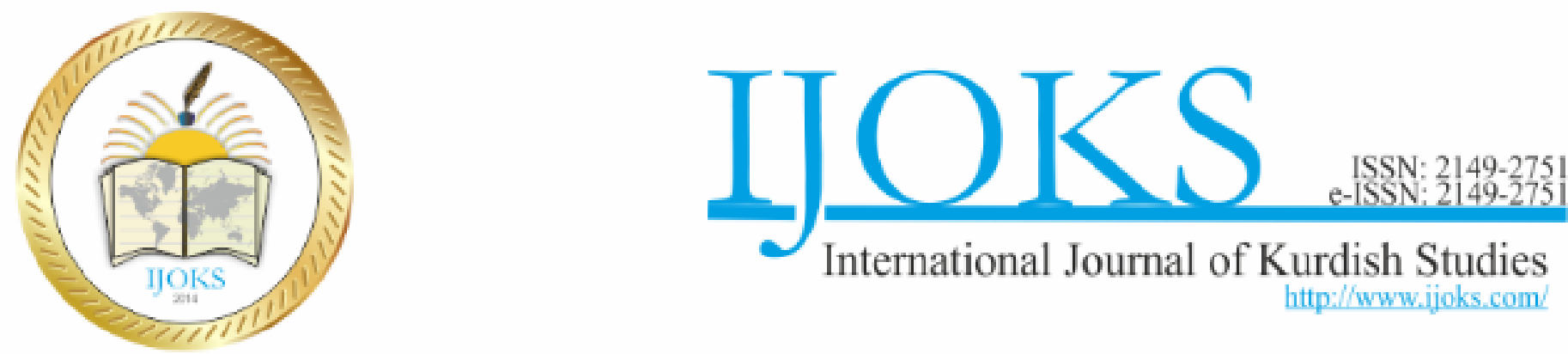

\title{
Article
}

International Journal of Kurdish Studies

6 (1), pp. $104-119$

http://ijoks.com

\section{Russia in the Middle East: A New Perspective on the Corporatization of Foreign Policy}

\author{
Mehmet Akif Koç ${ }^{1}$
}

Received: Jan 05, 2020 Reviewed: Jan 07, $2020 \quad$ Accepted: Jan 09, 2020

\begin{abstract}
The Middle East has emerged as a new stage for Moscow's increasingly active foreign policy due to its geopolitical relevance, close proximity to Russian borders, and abundance of energy resources. Although Russian interests in the Middle East are generally not considered vital and existential relative to post-Soviet geography and Europe, influence in this region is still essential for Moscow to regain its superpower status. Russia employs a combination of hard- and soft-power elements toward Middle Eastern actors. To this end, the instrumentalization of energy cooperation and arms sales is crucial for Russia to advance its goals in the region. The Kremlin also compartmentalizes its relations with almost all regional actors and establishes businessoriented networks to gain prestige, cultivate political influence, and benefit financially. After reorganizing the domestic political and economic power structure, Russian policy-makers have successfully mobilized stateowned energy and arms companies, such as Rosoboronexport, Rosatom, Rosneft, Gazprom, and Lukoil, as remarkable pillars of Russian policy toward the Middle East.
\end{abstract}

Keywords: Russia, Middle East, energy, geopolitics, arms

\section{Recommended citation:}

Koç, M.A. (2020). Russia in the Middle East: A New Perspective on the Corporatization of Foreign Policy. International Journal of Kurdish Studies 6 (1), $104-119$

DOI: https://doi.org/10.21600/ijoks. 670457

\footnotetext{
${ }^{1}$ Corresponding Author, Ph.D Candidate, Middle East Studies, Social Sciences University of Ankara (ASBU) Ankara / Turkey, E-mail: akifkoc@ @otmail.com
} 


\section{Introduction}

The Middle East has been one of the most significant for Moscow's evolving foreign policy orientation. Its geopolitical relevance, close proximity to Russian borders, and abundance of energy resources increase the region's value for Russian diplomatic agenda. Modern Russia policies toward the Middle East inherit some of the Soviet-era connections and networks in the region but also reflect crucial differences from the past in terms of political, economic, and commercial parameters. Moscow's efforts to establish closer ties with the region's energy sector through deals on oil, natural gas, and nuclear energy, as well as its push to strengthen its arms trade and military cooperation with regional actors, add more layers to its existing political and economic priorities. To enhance these efforts, Russian policy-makers use stateowned energy and arms giants, Rosoboronexport, Rosatom, Rosneft, Gazprom, and Lukoil, as main instruments of Russian policy in the region.

\section{Theoretical and Conceptual Framework}

In international relations, states (mainly regional and global powers) are generally inclined to instrumentalize non-military methods and tools (such as foreign aid and financial assistance, soft-power displays, diplomatic channel extension, etc. $)^{2}$ to increase their economic and political power, shape the policies of other actors, and create a sphere of influence.

The most widespread and effective foreign policy instrument is economic influence. ${ }^{3}$ As Newnham (2011) states, theorists of economic influence emphasize several factors that enable a state to successfully use its economic power against other states-two of them remain important in the modern era and help explain the Russian case:

i) size of initiating state relative to target state

ii) bilateral trade share held by each other

\footnotetext{
${ }^{2}$ Daryl Press and Benjamin Valentino (2006), “A Balanced Foreign Policy”, In How to Make America Safe: New Policies for National Security, Stephen Van Evera (Ed.), (Cambridge, MA: The Tobin Project); Stephen M. Walt (2013), “Which Works Best: Force or Diplomacy?”, Foreign Policy, (August 21, 2013), retrieved January 7, 2020 from https://foreignpolicy.com/2013/08/21/which-works-best-force-or-diplomacy/ ${ }^{3}$ A.S. Sonmez and S. Cobanoglu (2016), "The Use of Energy Resources as Foreign Policy Tools: The Russian Case", European Scientific Journal, April 2016 edition, vol.12, No.11, 81-82.
} 
If the initiating state has a larger economy than its target and conducts a lower proportion of its trade with its target, the initiating state's use of economic influence is more successful. ${ }^{4}$ Russian relations with post-Soviet countries (as well as other European states) perfectly fit this model, especially regarding energy trade. The model is also useful for examining Russian policy toward the Middle East, though additional parameters vary for regional context.

As an important component of economic status, energy resources have become an integral part of foreign and national security policies. Today, states perceive energy security to be equally as important as military or economic security. ${ }^{5}$ Some scholars highlight the inseparable nature of energy politics from foreign policy and the inevitable entanglement of energy and security policies for both producer and consumer states. Since energy resources can be used to put pressure on consumers, some producers frequently use energy as a "weapon" to influence consuming countries in order to advance certain foreign policy goals. ${ }^{6}$

According to a European Parliament Think Tank report on energy and foreign policy (2018), there is a close relationship between authoritarian characteristics of a state and the use of energy as a foreign policy tool. Analyzing countries' scores on the Freedom House index and their tendencies to instrumentalize energy resources, the report claims that energy-rich authoritarian states have wielded geopolitical influence through their energy assets. ${ }^{7}$

Regarding arms sales, as Nistico and others (2018) argue, international transfers of major conventional weapons constitute one of the most dynamic sectors of international trade - the arms trade, security, and energy dependence are heavily interconnected. On the demand side, defense and security are the main objectives; on the supply side, arms are exported to support the security needs of allies and to strengthen security links. ${ }^{8}$ The arms trade has political and economic dimensions, so the direction of weapon flows explains a lot about the nature of interdependence for both consumer and supplier states.

\footnotetext{
${ }^{4}$ Randall Newnham (2011), “Oil, carrots, and sticks: Russia's energy resources as a foreign policy tool”, Journal of Eurasian Studies 2, 134-135.

5 Julijus Grubliauskas and Michael Rühle (2018), "Energy security: a critical concern for Allies and partners", NATO Review, (July 26, 20118), retrieved January 21, 2020 from https://www.nato.int/docu/review/articles/2018/07/26/energy-security-a-critical-concern-for-allies-andpartners/index.html

${ }^{6}$ Giedrius Česnakas (2016), "Energy resources as the tools of foreign policy: the case of Russia", Lithuanian Foreign Policy Review vol. 35. DOI: 10.1515/lfpr-2016-0002.

${ }^{7}$ Rem Korteweg (2018), "Energy as a tool of foreign policy of authoritarian states, in particular Russia”, EU Parliament Think Tank Report, last modified on April 27, 2018, available at http://www.europarl.europa.eu/thinktank/en/document.html?reference=EXPO_STU(2018)603868, 8-11. ${ }^{8}$ R. Nistico, V. Bove and C. Deiana (2018), "Global arms trade and oil dependence", Journal of Law Economics and Organization 34(2) · February 2018, 272-299.
} 


\section{Main Parameters of Russian Policy in the Middle East: Return to the Global Stage}

During the Cold War, the Middle East became a primary chessboard between the two superpowers; the proxy conflict was seen through the rampant pursuit of regional allies. PostWWII Soviet policy in the region was motivated by two crucial approaches: i) installing proSoviet regimes to protect its southern borders and ii) benefitting from the growing anticolonialist sentiment among the Arab peoples to undermine Western power in the region. As a result, the Middle East remained a "key" area of interest for Soviet policy-makers throughout the Cold War. ${ }^{9}$ Moscow's approach to the region was consistent with the Cold War mentality of confrontation between the two systems, so the USSR established alliances with the states most closely aligned with its own political orientation. ${ }^{10}$ Egypt, Iraq, Algeria, and Libya emerged as the main allies of Moscow under the harsh conditions of the Cold War. However, when the USSR dissolved in the early 1990s, Moscow lost its powerful position in the region.

Some Russian scholars argue that withdrawal from the Middle East in the late 1980s marked the decline of the Soviet Union's superpower status. Today, Russia has reappeared as a major player in the Middle East under Vladimir Putin's rule to re-establish itself as a great power. Beginning with the military intervention in Syria in 2015, the Middle East is seen as a key testing ground for the Kremlin's attempt to return to the global stage. ${ }^{11}$

In order to achieve this goal, Russia relies on a wide array of diplomatic, military, intelligence, trade, energy, and financial tools to influence political systems, public attitudes, and local elites. It does this not only in the Middle East but also in Europe, Africa, Asia, and Latin America. These initiatives mainly aim, in a manner reminiscent of the Cold War, to undermine the US-led international order and the cohesion of the West while at the same time promoting Russian commercial, military, and energy interests. ${ }^{12}$

Russian foreign policy-makers are more successful than those in the US at being pragmatic and compartmentalizing its relations with regional actors to prevent the potential negative

\footnotetext{
${ }^{9}$ M. Duric and T. Lansford (2017), "US-Russian Competition in the Middle East: Convergences and Divergences in Foreign Security Policy", in J. Covarrubias and T. Lansford (Eds.), Strategic Interests in the Middle East: Opposition and Support for US Foreign Policy, (New York: Routledge), 63-64.

${ }^{10}$ Alexey Malashenko (2013), Russia and the Arab Spring, (Moscow: Carnegie Moscow Center), 3-4.

${ }^{11}$ Dmitry Trenin (2016), "Russia in the Middle East: Moscow's Objectives, Priorities, and Policy Drivers", Carnegie Moscow Center (April 5, 2016), retrieved January 20, 2019 from https://carnegie.ru/2016/04/05/russiain-middle-east-moscow-s-objectives-priorities-and-policy-drivers-pub-63244

Anna Borshchevskaya (2016), Russia in the Middle East: Motives, Consequences, Prospects. (Washington: The Washington Institute for Near East Policy - Policy Focus), 4-6.

${ }^{12}$ Paul Stronski and Richard Sokolsky (2017), The Return of Global Russia: An Analytical Framework.

(Washington: Carnegie Endowment for International Peace Paper), 3-4.
} 
effects of conflicting parties' interests over its main policies. Moscow's strategy of establishing sustainable connections (with all actors, including states, armed groups, local elites, etc.), one that often ignores its own "terrorist" designations, creates remarkable room for maneuvering to effectively balance Western power in the region. As Shumilin (2016) argues, this policy allows President Putin to adopt a pragmatic stance toward regional issues. For example, Russia opposes Saudi Arabia in Syria, but cooperates with it on energy and arms sales ${ }^{13}$; at the same time, Moscow also cooperates closely with Iran and Qatar, with whom Riyadh has tense relations. Russia's strategy in the Middle East can be defined as "transactional, non-ideological, and flexible" on the basis of the Kremlin's main regional drivers of "international prestige, trade, and regional stability." 14

\section{New Foreign Policy Instruments in Russian Foreign Policy}

As a macro strategy, Russia aims to increase its sphere of influence, refurbish its image, and assert itself on key international issues where Western retreats have left vacuums by challenging Western political, economic, and security institutions. To do this, Russian policymakers use these methods and tools: i) economic and energy, ii) political and cultural, iii) digital media and cyber, and iv) military and security. ${ }^{15}$

As Bremer \& Charap (2007) point out, since Vladimir Putin was named acting president on December 31, 1999, authority has become concentrated in the Kremlin and the executive branch has asserted control over state-owned enterprises that had previously been driven by the private interests of Yeltsin-era economic politics and operated with some independence. As a result, the Kremlin monopolized Russian domestic and foreign policy as well as the country's economy and society. This new phase was heavily dominated by siloviki, representatives of security and intelligence institutions (mostly from Putin's inner circle). Positions in the bureaucracy, economic structures, and political institutions were largely filled by the members of siloviki. One of the most important features of the siloviki members is their passion for economic nationalism and restoring Russia's international greatness. ${ }^{16}$ To this end,

\footnotetext{
${ }^{13}$ Alexander Shumilin (2016), Russia's Diplomacy in the Middle East: Back to Geopolitics, Institut français des relations internationals (IFRI), (May 1, 2016), retrieved January 21, 2019 from https://www.ifri.org/sites/default/files/atoms/files/rnv93_version_uk_final_protege.pdf

${ }^{14}$ James Sladden, Becca Wasser, Ben Connable, and Sarah Grand-Clement (2017), Russian Strategy in the Middle East. (Washington: RAND Corporation - Perspective Paper), 3-11.

${ }^{15}$ Stronski and Sokolsky (2017), The Return of Global Russia, pp. 29-30.

16 Ian Bremmer and Samuel Charap (2007), “The Siloviki in Putin's Russia: Who They Are and What They Want”, The Washington Quarterly, 30:1, 83-92, DOI: 10.1162/wash.2006-07.30.1.83.
} 
the strategic management of the huge raw materials sector and industrial complexes were restructured and put under the rule of siloviki members.

As part of the ambitious "return to global power politics" approach, energy and arms sales are considered crucial foreign policy tools. According to BP statistics (2017), Russian oil production is at $11.3 \mathrm{Mb} / \mathrm{d}$, accounting for $12.2 \%$ of the global total. Russia is the secondlargest (after the US) gas producer with $17.3 \%$ of global output. Russian oil exports grew by $3.1 \%$ (to $8.6 \mathrm{Mb} / \mathrm{d}$ ) to account for $12.7 \%$ of the global total while gas exports grew by $7.9 \%$ (to $231 \mathrm{bcm}$ ) to account for $25.9 \%$ of global gas export growth in $2018 .{ }^{17}$ In the energy sector, the powerful public giants Rosneft, Gazprom, and Lukoil have extensive global operations stretching throughout Afro-Eurasia; Middle Eastern energy investment has ramped up in recent years.

Furthermore, Russian state-owned nuclear company Rosatom has become the second-largest nuclear power company in the world in terms of installed nuclear capacity and number of nuclear units in operation. The Kremlin has also consolidated its strong position in the global arms trade and shares the title of top arms exporters with the US; Rosoboronexport, a federalstate unitary enterprise, is the key organization behind Russian arms exporting capacity.

\section{Russian Energy Giants and Middle East Activities}

Russia has significant economic interests in the Middle Eastern energy sector. Rosneft and Gazprom, Russian state-owned energy companies, maintain important energy projectsincluding key consumer markets, oil and gas fields, and customers for nuclear energy infrastructure - in countries and regions such as Iran, Iraq, and Turkey, as well as Iraqi Kurdistan and the eastern Mediterranean. ${ }^{18}$

Rosneft is the world's largest listed oil company (based on production volume), producing 5 million barrels of oil daily (ExxonMobil produces 4 million barrels per day). The Russian state owns just over $50 \%$ of its shares; its CEO, Igor Sechin, maintains close personal ties with President Putin. According to Russian experts, the Kremlin has not been shy to exert

\footnotetext{
${ }^{17}$ BP Country Insight - Russia (2017), BP, (last modified on January 10, 2019), retrieved January 15, 2019 from https://www.bp.com/en/global/corporate/energy-economics/statistical-review-of-world-energy/country-andregional-insights/russia.html

${ }^{18}$ Sladden and others (2017), Russian Strategy in the Middle East, 7-8.
} 
control over the energy company despite its commercial status. Rosneft's huge investments in Venezuela, Iraq, and India reflect the Russian state's control over the energy giant. ${ }^{19}$

Rosneft's Middle Eastern investments focus on Iraqi Kurdistan and Egypt. During the referendum crisis between Erbil and Baghdad in 2017-2018, Rosneft took over ownership of Iraqi Kurdistan's landlocked oil export pipelines to Turkey from the Erbil government in return for $\$ 1.8$ billion. Control of the strategic pipelines has given Rosneft (and, in turn, the Russian government) a crucial role in ongoing talks between the KRG and Baghdad, as well as Iraqi politics in general. Rosneft's recent initiatives in Iraq are viewed as political more than they are commercial. ${ }^{20}$

In October 2017, Rosneft closed a deal to acquire from ENI a 30\% stake in the Zohr gas field (one of the largest in the Mediterranean, located off the coast of Egypt) in exchange for over $\$ 2$ billion; the Russian firm produces gas with the Italian ENI (60\%) and British BP (10\%) in Egypt as a result of the deal. ${ }^{21}$ Rosneft also began drilling oil at Block 12 field in southern Iraq alongside its investments in Iraqi Kurdistan to the north. Rosneft's other significant energy investment activities in the Middle East are as follows: signed deal to buy $20-35 \mathrm{~m}$ barrels/year of crude oil from Libya and redevelop oilfields (February 2017); bought Egyptian crude oil for the first time and signed deal to supply Egypt with LNG (March 2017); bid for offshore rights in Lebanon. ${ }^{22}$ The positive trend in Russia's strengthened relations with two North African strongmen, Egyptian el-Sisi and Libyan Haftar, coincides with Rosneft's investments in the Mediterranean basin. Rosneft seeks to establish a partnership with Saudi Aramco and buy shares of the oil giant in 2018. It is currently in the process of signing a deal with Iranian NIOC to team up on oil and gas projects worth $\$ 30$ billion. $^{23}$

\footnotetext{
${ }^{19}$ Vanand Meliksetian (2018), "Rosneft's Middle East Strategy Explained", Oilprice, (November 10, 2018), retrieved January 18, 2019 from https://oilprice.com/Geopolitics/International/Rosnefts-Middle-East-StrategyExplained.html

${ }^{20}$ Dmitry Zhdannikov (2018), “The great Russian oil game in Iraqi Kurdistan”. Reuters, (April 19, 2018), retrieved January 11, 2019 from https://www.reuters.com/article/us-rosneft-iraq-insight/the-great-russian-oilgame-in-iraqi-kurdistan-idUSKBN1HQ1R3 ; Meliksetian, "Rosneft's Middle East Strategy Explained".

${ }^{21}$ ROSNEFT Annual Report (2017), ROSNEFT, 159-160, retrieved from https://www.rosneft.com/upload/site2/document file/a_report_2017_eng.pdf

${ }^{22}$ Henry Foy and David Sheppard (2017), "Rosneft takes key step in push into Middle East", Financial Times, (April 3, 2017), retrieved January 10, 2019 from https://www.ft.com/content/5417e004-13a4-11e7-80f4$13 \mathrm{e} 067 \mathrm{~d} 5072 \mathrm{c}$

${ }^{23}$ Denis Pinchuk and Vladimir Soldatkin (2017), "Russia's Rosneft, Iran's NIOC agree to team up on oil and gas projects worth $\$ 30$ billion", Reuters, (November 1, 2017), retrieved January 5, 2019 from https://www.reuters.com/article/us-russia-iran-oil/russias-rosneft-irans-nioc-agree-to-team-up-on-oil-and-gasprojects-worth-30-billion-idUSKBN1D14P6
} 
In addition to Rosneft's huge investments, Russian oil and gas companies Lukoil and Gazprom Neft are also involved in Middle Eastern projects; both companies are directed by Putin allies Vagit Alekperov and Alexey Miller respectively. Gazprom, the state-controlled gas monopoly (Russia's largest company with $\$ 117$ billion in sales and the world's largest natural gas producer), dominates European energy politics and grants leverage to the Kremlin as an effective foreign policy tool; in recent years, Gazprom has begun to invest in the Middle Eastern energy sector, as has Lukoil.

As Borshchevskaya (2016) highlights, the Kremlin agreed to write off some of Iraq's Sovietera debt in 2005 around the same time Lukoil provided several million dollars of humanitarian aid to Iraq. In February 2008, Russia forgave the entirety of Iraq's \$12.9 billion in debt. Since 2009, Lukoil and Gazprom Neft have won a number of large contracts in Iraq. Lukoil plans to make West Qurna-2 one of Iraq's largest producers. Lukoil has also played a major role as an energy exporter in Iraqi Kurdistan. In 2012, Gazprom Neft signed two deals with the KRG, making it the fourth major oil company to enter the region and putting it in the same league as US-based Chevron and ExxonMobil and France-based Total. ${ }^{24}$ Gazprom Neft and its partners developing Iraq's Badra oil field plan to invest an additional \$2.5 billion in the project by $2030 .^{25}$ Gazprom Neft is also seeking to take part in Abu Dhabi's oil projects and plans to partner with Mubadala Investment Holding in the UAE, Egypt, Oman, and Iraq. ${ }^{26}$

According to Sonmez \& Cobanoglu (2016), Russia uses energy in its foreign policy through three main strategies: i) importing cheap natural gas and oil from its allies and cooperating states, ii) using price negotiations as a "carrot and stick" method over consumer countries, and iii) utilizing the option to change gas and oil routes and pipelines to align with its foreign and security policy goals. ${ }^{27}$ However, in the Middle East, Russia's strategy differs from postSoviet European strategies. For example, the Kremlin's pragmatic approach to the Gulf, Saudi Arabia in particular, is based on a desire to increase or maintain global oil prices, at least not to allow decreasing; to this end, Russia tries to coordinate its efforts with Arabian OPEC

\footnotetext{
${ }^{24}$ Borshchevskaya (2016), Russia in the Middle East, 32-34.

${ }^{25}$ Reuters (2017), “Investment In Iraq’s Badra Oil Field To Reach \$2.5 Billion By 2030”, Reuters, (December 7, 2017), retrieved January 14, 2019 from https://www.epmag.com/investment-iraqs-badra-oil-field-reach-25billion-2030-1672996

${ }^{26}$ Dania Saadi (2018),"Gazprom Neft keen to take part in Abu Dhabi's oil projects and discoveries", the National, (November 15, 2018), retrieved January 15, 2019 from https://www.thenational.ae/business/energy/gazprom-neft-keen-to-take-part-in-abu-dhabi-s-oil-projects-anddiscoveries-1.791792

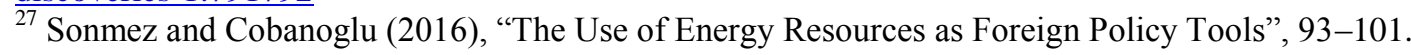


states through production levels and price measure agreements. ${ }^{28}$ Together, the Middle East and Russia possess $60 \%$ and $63 \%$ of the world's proven oil and gas reserves, respectively; they produce half of the world's oil and nearly $40 \%$ of its gas. Any cooperation between them will, therefore, have significant implications for global oil and gas markets. ${ }^{29}$

\section{ROSATOM and Russian Nuclear Policy}

Russia has not only maintained its dominance over oil and natural gas but has identified new energy options, mainly nuclear power. Russian leadership has sought to lead the global active nuclear power market. The Kremlin consolidated Russia's nuclear industry in a single stateowned company, Rosatom, in $2007 .^{30}$

According to Rosatom's reports, it operates in uranium mining, enriched uranium product delivery, nuclear fuel and component delivery, and nuclear power plant construction. Rosatom leads globally in terms of the number of reactors being built abroad with a total of 35. The company is operational in more than 40 countries and holds $16 \%$ of the global nuclear fuel market share. Its portfolio of overseas projects for the next decade exceeds $\$ 133$ billion. $^{31}$

In addition to its ongoing relations with traditional buyers in Europe and Asia, Rosatom has followed in the footsteps of Russian oil and gas giants in the Middle East by securing nuclear plant construction deals with Turkey and Iran; the company seeks to further expand its market share in the region. In Jordan, Rosatom has conducted nuclear feasibility studies to install a $2 \mathrm{GW}$ reactor. In addition, it signed a deal with the UAE to supply nuclear fuel to the Korean Barakah nuclear plant. Saudi Arabia also plans to develop 17GW of nuclear power by 2040 Rosatom is on Riyadh's shortlist for construction partners. Finally, Egypt signed a preliminary agreement with Rosatom to build a $4.8 \mathrm{GW}$ power plant in Dabaa, which the company hopes will be up and running by $2026 .{ }^{32}$

\footnotetext{
${ }^{28}$ Sladden and others (2017), Russian Strategy in the Middle East, 8.

${ }^{29}$ Carole Nakhle (2018), "Russia's energy diplomacy in the Middle East", in N.Popescu and S. Secrieru (Eds.), Russia's Return to the Middle East: Building Sandcastles? (Chaillot Paper No: 146, July 2018), 30.

${ }^{30}$ Rauf Mammadov and Theodore Karasik (2018), "Rosatom as a Tactic in Russia's Foreign Policy", International Policy Digest, (July 19, 2018), retrieved January 9, 2019 from https://intpolicydigest.org/2018/07/19/rosatom-as-a-tactic-in-russia-s-foreign-policy/

${ }^{31}$ ROSATOM (2019), "International Relations of Rosatom", (January 1, 2019), retrieved January 2, 2019 from https://www.rosatom.ru/en/global-presence/international-relations/

${ }^{32}$ Mammadov and Karasik (2018), "Rosatom as a Tactic in Russia's Foreign Policy"; ROSATOM (2017), "Public Annual Report - 2017”, retrieved January 13, 2019 from https://rosatom.ru/upload/iblock/29c/29c061878dad37c189db341648c964b3.pdf , 29-30.
} 
Nuclear energy diplomacy significantly adds to Russian prestige and creates political gains in terms of interdependence. However, the main motivation behind Russian nuclear power plant construction abroad is economic. As Minin and Vlcek (2017) states clearly, "four-unit nuclear power plant construction by Rosatom keeps 24,000 people in work in various segments of the nuclear industry inside Russia, while each ruble of the nuclear loan brings 1.8 rubles into the economy by way of orders for Russian enterprises, including fuel supplies, staff training, decommissioning services, and so on. Each ruble also provides 0.54 rubles of direct income to the Russian budget.",33

\section{Rosoboronexport and Russia's Increasing Share in the Global Arms Trade}

Rosoboronexport was founded as a state-owned arms production company following the chaotic organization of the Russian arms trade in the 1990s, alongside competition between private companies and state agencies, to centralize decision-making for the defense industry. President Putin chose Sergey Chemezov, a close ally, to direct the process and found the company. $^{34}$

Since 1950, the US and Russia (the USSR before 1992) have consistently been the largest suppliers of arms (the US with 34\% global market share, Russia with 22\%). The flow of arms to the Middle East increased by $103 \%$ between 2008-12 and 2013-17. On the top arms importers list, Saudi Arabia follows India with a global share of 10\% (India with 12\%); Egypt places third with $4.5 \%$ while the UAE holds fourth with $4.4 \%$ share, Algeria holds seventh with $3.7 \%$, and Iraq holds eighth with $3.4 \% .^{35}$

Russia began developing a three-dimensional arms strategy after reorganizing its domestic defense industry management, through which the Kremlin instrumentalized arms sales as a foreign policy tool: i) license transfers with occasional joint military hardware development (currently only with India to its full extent), ii) large-scale deliveries to relatively prosperous countries that can afford to pay for military hardware (Indonesia, Malaysia, Algeria, Iraq, Azerbaijan, etc.), and iii) the "small steps toward big gains" approach (military-technical cooperation aimed at developing countries, mainly poor- and medium-tier states in Africa,

\footnotetext{
${ }^{33}$ Nikita Minin and Tomas Vlcek (2017), "Determinants and Considerations of Rosatom's External Strategy", Energy Strategy Reviews, Vol. 17 (September 2017), 37-44.

${ }^{34}$ Louis-Marie Clouet (2007), Rosoboronexport, Spearhead of the Russian Arms Industry. (Paris: IFRI Russia Report, Russie.nei.Visions No: 22, 2007), 5-6.

${ }^{35}$ Stockholm International Peace Research Institute (SIPRI) (2018), "SIPRI Yearbook 2018: Armaments, Disarmament and International Security", retrieved January 15, 2019 from https://www.sipri.org/sites/default/files/2018-06/yb_18 summary_en_0.pdf , 7-8.
} 
Latin America, and Southeast Asia). This multi-dimensional strategy demonstrates the variety of tools that Russia employs to extract profit, strengthen its political sphere of influence, build up regional influence, and maintain and strengthen relations with strategic partners in various regions. $^{36}$

As Sladden and others (2017) argue, Russia is making a concerted effort to reclaim its role as the "credible" arms supplier of choice for Middle Eastern governments. During the Arab Spring, the US remarkably lost its position and relative advantage in the region, allowing Russia to re-emerge and dominate the arms market. Arab governments in recent years tend to prefer military cooperation with Russia due to i) Rosoboronexport's quick delivery of muchneeded weaponry (as demonstrated through its provision of attack helicopters to Iraq), ii) Moscow's non-ideological approach to relationships and provision to a diverse group of actors simultaneously, and iii) the US legislature's reluctance to permit weapon trades due to human rights concerns and Israeli interests (shown by delays in recent arms sales to Egypt and Saudi Arabia). As a result, Russia's arms exports to Middle East countries increased by $36 \%$ between 2011 and $2015 .^{37}$

The most popular Russian arms in the Middle East are tanks, propelled guns, armored vehicles, supersonic combat aircraft, and anti-aircraft missiles; Rosoboronexport also delivers helicopters, surface-to-surface missiles, and anti-ship missiles to state actors. Some recent estimates show that up to $37 \%$ (or $\$ 5.5$ billion) of Russian arms exports in 2015 were to clients in the Middle East, which, in absolute terms, is ten times higher than all Russian arms exports to the region during the 1990 s. $^{38}$ The Middle East has been the second-most important region for Russian arms exports over the last several decades; it accounted for $17.8 \%$ of the total between 2000 and 2016. This market comprises of traditional (Soviet-era) customers, such as Iraq (1.4\%), Syria (1.4\%), Egypt (1.4\%), and Yemen (1.2\%), as well as newer clients, such as Algeria (9.1\%), Iran (2\%), and the UAE (0.7\%). According to SIPRI's global armament report, Middle Eastern countries' dependence figures on Russian arms sales are as

\footnotetext{
${ }^{36}$ Ilya Kramnik (2014), "Russian Arms Export: Strategies of Influence”, Russian International Affairs Council (RIAC), (March 11, 2014), retrieved January 10, 2019 from http://russiancouncil.ru/en/analytics-andcomments/analytics/russian-arms-export-strategies-of-influence/ ${ }^{37}$ Sladden and others (2017), Russian Strategy in the Middle East, 8.

${ }^{38}$ Yury Barmin (2018), Russian Arms Diplomacy in the Middle East, (Istanbul: Al-Sharq Forum, 2018), 8-10.
} 
follows: Algeria (>80-100\%), Syria (>60-80\%), Iran (>40-60\%), Yemen $(>40-60 \%)$, and Libya $(>20-40 \%){ }^{39}$

Egypt is one of the biggest consumers of Russian arms in the Middle East. Cairo played a key role in the 1950s to give Moscow a foothold in the region during the chaos of the Cold War. Following the military coup of el-Sisi, Washington froze its aid to Cairo, allowing Russia to once again reach out to Egypt. As a result, Moscow and Cairo reached an arms agreement in 2014 worth $\$ 3.5$ billion. In February 2017, Abu Dhabi entered into military contracts with Russia worth $\$ 1.9$ billion that included MG-29 twin-engine aircraft and SU-35 jets. Rosoboronexport's arms deal with Algeria in 2006 was worth \$7.5 billion. In 2012, the Kremlin supplied Iraq with military equipment worth $\$ 4.2$ billion. $^{40}$

An increasingly influential dimension of Russian foreign policy's military framework is the use of "private" military companies and mercenaries, such as Wagner in Syria and many others in Ukraine, Libya, and various conflict zones. ${ }^{41}$ Most recently, according to field-based observers, 600-800 Russian mercenaries are currently fighting with Commander Khalifa Haftar to capture the Libyan capital of Tripoli as of December 2019. ${ }^{42}$ These direct interventions contribute to further escalation and internationalization of the Libyan conflict.

\section{Conclusion}

President Putin, as a leader with a background in the KGB who witnessed the demise of the USSR during his foreign mission in East Germany, described the collapse of the Soviet Union as a "major geopolitical disaster of the century" in his annual address to the Federal Assembly of the Russian Federation in April 2005. ${ }^{43}$ According to a recent poll from November 2015 of 1,600 Russian citizens, two-thirds believe Russia is a great power-an increase from half in 2011 and $31 \%$ in $1999 .{ }^{44}$ This author argues that there are two main factors feeding into this

\footnotetext{
${ }^{39}$ Richard Connoly and Cecilie Sendstad (2017), Russia's Role as an Arms Exporter: The Strategic and Economic Importance of Arms Exports for Russia. (London: Chatham House - Research Paper); 6, 17-18.

${ }^{40}$ Kramnik (2014), "Russian Arms Export"; Barmin, Russian Arms Diplomacy, 10-11.

${ }^{41}$ Nicu Popescu and Stanislav Secrieru (2018), Russia's return to the Middle East Building sandcastles? (Paris: EU Institute for Security Studies - Chaillot Papers, No: 146), 24-25.

${ }^{42}$ Maggie Michael (2019), "Libyan officials collect evidence of Russian fighters in war", AP (December 5, 2019), retrieved January 6, 2020 from https://apnews.com/5cb85022f79e4af391007d74b6edc0f2

${ }^{43}$ Vladimir Putin (2005), "Annual Address to the Federal Assembly of the Russian Federation", (April 25, 2005), retrieved January 2, 2019 from http://en.kremlin.ru/events/president/transcripts/22931

${ }^{44}$ Borshchevskaya (2016), Russia in the Middle East, 50.
} 
positive trend in Russian public opinion: i) stable domestic economic conditions due to relatively high oil and gas prices in recent years and ii) the Kremlin's successful and ambitious foreign policy moves to regain superpower status, particularly within the context of Ukraine and Syria. When Putin's statement is evaluated alongside Russian public opinion on great power status, the Kremlin's optimal strategy involves the realpolitik foreign policy that it has developed over the last 18 years.

Due to its geopolitical relevance, possession of almost half of global oil and natural gas reserves, close proximity to Russian borders, the Middle East is an appropriate stage for Moscow's revitalized foreign policy. Russian interests in the Middle East are not generally viewed as vital or existential compared to the post-Soviet geography and action in Europe, but this region is still significant for Moscow to reclaim its superpower status. Russia employs a combination of hard- and soft-power elements toward Middle Eastern actors. The instrumentalization of energy cooperation and arms sales has provided crucial leverage for Russia in the region. The Kremlin also wisely compartmentalizes its relations with all regional actors and establishes business-oriented networks to gain prestige, cultivate political influence, and benefit financially. Russian policy-makers, after reorganizing domestic power structures, have successfully mobilized state-owned energy and arms giants such as Rosoboronexport, Rosatom, Rosneft, Gazprom, and Lukoil as pillars of Russian foreign policy in the Middle East.

The Russian energy companies Rosneft, Gazprom Neft, and Lukoil have remarkably significant oil and gas investments in Iraq, Egypt, and Libya; these firms are also partnered with the Gulf States to cooperate on setting global output and prices. Russia is also active in the nuclear energy sector. The state-owned company Rosatom has signed deals to construct nuclear plants in Iran, Turkey, Egypt, and Jordan. Additionally, it has agreed to supply nuclear fuel to the reactor in the UAE and is in ongoing negotiations with Saudi Arabia to construct reactors there. Furthermore, Rosoboronexport has inherited the Soviet-era arms trade network in the region (Iraq, Syria, Egypt, and Yemen) and added new markets (Algeria, Iran, UAE). It has largely secured the region for Russia's high-technology Russian arms industry due to its quick supply channels and non-ideological approach. 


\section{REFERENCES}

Barmin, Yury (2018). Russian Arms Diplomacy in the Middle East. Istanbul: Al-Sharq Forum.

Borshchevskaya, Anna (2016). Russia in the Middle East: Motives, Consequences, Prospects. Washington: The Washington Institute for Near East Policy - Policy Focus.

BP Country Insight - Russia (2017). BP. (last modified on January 10, 2019), retrieved January 15, 2019 from https://www.bp.com/en/global/corporate/energyeconomics/statistical-review-of-world-energy/country-and-regionalinsights/russia.html

Bremmer, Ian and Charap, Samuel (2007). The Siloviki in Putin's Russia: Who They Are and What They Want. The Washington Quarterly, 30:1, 83-92, DOI: 10.1162/wash.200607.30.1.83.

Clouet, Louis-Marie (2007). Rosoboronexport, Spearhead of the Russian Arms Industry. Paris: IFRI Russia Report, Russie.nei.Visions No: 22.

Connoly, Richard and Sendstad, Cecilie (2017). Russia's Role as an Arms Exporter: The Strategic and Economic Importance of Arms Exports for Russia. London: Chatham House - Research Paper.

Česnakas, Giedrius (2016). Energy resources as the tools of foreign policy: the case of Russia. Lithuanian Foreign Policy Review vol. 35. DOI: 10.1515/lfpr-2016-0002.

Duric, M. and Lansford, T. (2017). US-Russian Competition in the Middle East: Convergences and Divergences in Foreign Security Policy. J. Covarrubias and T. Lansford (Eds.), In Strategic Interests in the Middle East: Opposition and Support for US Foreign Policy. New York: Routledge.

Foy, Henry and Sheppard, David (2017). Rosneft takes key step in push into Middle East. Financial Times, (April 3, 2017). retrieved January 10, 2019 from https://www.ft.com/content/5417e004-13a4-11e7-80f4-13e067d5072c

Grubliauskas, Julijus and Rühle, Michael (2018). Energy security: a critical concern for Allies and partners. NATO Review, (July 26, 20118), retrieved January 21, 2020 from https://www.nato.int/docu/review/articles/2018/07/26/energy-security-a-criticalconcern-for-allies-and-partners/index.html

Korteweg, Rem (2018). Energy as a tool of foreign policy of authoritarian states, in particular Kramnik, Ilya (2014). Russian Arms Export: Strategies of Influence. Russian International Affairs Council (RIAC), (March 11, 2014), retrieved January 10, 2019 from http://russiancouncil.ru/en/analytics-and-comments/analytics/russian-armsexport-strategies-of-influence/

Russia. EU Parliament Think Tank Report, last modified on April 27, 2018, available at http://www.europarl.europa.eu/thinktank/en/document.html?reference=EXPO_STU(2 018) 603868

Malashenko, Alexey (2013). Russia and the Arab Spring. Moscow: Carnegie Moscow Center.

Mammadov, Rauf and Karasik, Theodore (2018). Rosatom as a Tactic in Russia's Foreign Policy. International Policy Digest, (July 19, 2018), retrieved January 9, 2019 from https://intpolicydigest.org/2018/07/19/rosatom-as-a-tactic-in-russia-s-foreign-policy/

Meliksetian, Vanand (2018). Rosneft's Middle East Strategy Explained". Oilprice. Retrieved January 18, 2019 from https://oilprice.com/Geopolitics/International/Rosnefts-MiddleEast-Strategy-Explained.html

Michael, Maggie (2019). Libyan officials collect evidence of Russian fighters in war. AP (December 5, 2019), retrieved from https://apnews.com/5cb85022f79e4af391007d74b6edc0f2 
Minin, Nikita and Vlcek, Tomas (2017). Determinants and Considerations of Rosatom's External Strategy. Energy Strategy Reviews, Vol. 17 (September 2017), 37-44.

Nakhle, Carole (2018). Russia's energy diplomacy in the Middle East. N.Popescu and S. Secrieru (Eds.), Russia's Return to the Middle East: Building Sandcastles? Chaillot Paper No: 146, July 2018.

Newnham, Randall (2011). Oil, carrots, and sticks: Russia's energy resources as a foreign policy tool. Journal of Eurasian Studies 2, 134-143.

Nistico, R., Bove, V. and Deiana, C. (2018). Global arms trade and oil dependence. Journal of Law Economics and Organization 34(2) · February 2018, pp. 272-299.

Pinchuk, Denis and Soldatkin, Vladimir (2017). Russia's Rosneft, Iran's NIOC agree to team up on oil and gas projects worth $\$ 30$ billion. Reuters, (November 1, 2017), retrieved January 5, 2019 from https://www.reuters.com/article/us-russia-iran-oil/russiasrosneft-irans-nioc-agree-to-team-up-on-oil-and-gas-projects-worth-30-billionidUSKBN1D14P6

Popescu, Nicu and Secrieru, Stanislav (2018). Russia's return to the Middle East Building sandcastles? Paris: EU Institute for Security Studies - Chaillot Papers, No: 146.

Press, Daryl and Valentino, Benjamin (2006). A Balanced Foreign Policy. In Stephen Van Evera (Ed.), How to Make America Safe: New Policies for National Security. Cambridge, MA: The Tobin Project.

Putin, Vladimir (2005). "Annual Address to the Federal Assembly of the Russian Federation". (April 25, 2005), retrieved from http://en.kremlin.ru/events/president/transcripts/22931

Reuters (2017). Investment in Iraq's Badra Oil Field To Reach \$2.5 Billion By 2030. Reuters, (December 7, 2017), retrieved January 14, 2019 from https://www.epmag.com/investment-iraqs-badra-oil-field-reach-25-billion-20301672996

ROSATOM (2019). International Relations of Rosatom. (January 1, 2019), retrieved January 2, 2019 from https://www.rosatom.ru/en/global-presence/international-relations/

ROSATOM Public Annual Report (2017). Retrieved January 13, 2019 from https://rosatom.ru/upload/iblock/29c/29c061878dad37c189db341648c964b3.pdf

ROSNEFT Annual Report - (2017). ROSNEFT. retrieved January 7, 2020 from https://www.rosneft.com/upload/site2/document_file/a_report_2017_eng.pdf

Saadi, Dania (2018). Gazprom Neft keen to take part in Abu Dhabi's oil projects and discoveries. The National, (November 15, 2018), retrieved January 15, 2019 from https://www.thenational.ae/business/energy/gazprom-neft-keen-to-take-part-in-abudhabi-s-oil-projects-and-discoveries-1.791792

Shumilin, Alexander (2016). Russia's Diplomacy in the Middle East: Back to Geopolitics. Institut français des relations internationals (IFRI), (May 1, 2016), retrieved January 21 , 2019

from https://www.ifri.org/sites/default/files/atoms/files/rnv93_version_uk_final_protege.pdf

SIPRI Yearbook (2018). Armaments, Disarmament and International Security. Stockholm International Peace Research Institute (SIPRI), retrieved January 15, 2019 from https://www.sipri.org/sites/default/files/2018-06/yb_18_summary_en_0.pdf

Sladden, J., Wasser, B., Connable, B. and Grand-Clement, S. (2017). Russian Strategy in the Middle East. Washington: RAND Corporation - Perspective Paper.

Sonmez, A.S. and Cobanoglu, S. (2016). The Use of Energy Resources as Foreign Policy Tools: The Russian Case. European Scientific Journal, April 2016 edition, vol.12, No.11, 78-110.

Stronski, Paul and Sokolsky, Richard (2017). The Return of Global Russia: An Analytical Framework. Washington: Carnegie Endowment for International Peace Paper. 
Trenin, Dmitry (2019). Russia in the Middle East: Moscow's Objectives, Priorities, and Policy Drivers. Carnegie Moscow Center (April 5, 2016), retrieved January 20, 2019 from https://carnegie.ru/2016/04/05/russia-in-middle-east-moscow-s-objectivespriorities-and-policy-drivers-pub-63244

Walt, Stephen M. (2013). Which Works Best: Force or Diplomacy? Foreign Policy, (August 21, 2013), retrieved January 7, 2020 from https://foreignpolicy.com/2013/08/21/which-works-best-force-or-diplomacy/

Zhdannikov, Dmitry (2018). The great Russian oil game in Iraqi Kurdistan. Reuters, (April 19, 2018), retrieved January 11, 2019 from https://www.reuters.com/article/us-rosneftiraq-insight/the-great-russian-oil-game-in-iraqi-kurdistan-idUSKBN1HQ1R3 